\title{
Embodiment in the Museum - What is a Museum?
}

Incarnation des visiteurs au musée. Qu'est-ce qu'un musée?

\section{Jennifer Harris}

\section{(2) OpenEdition}

\section{Journals}

\section{Electronic version}

URL: http://journals.openedition.org/iss/422

DOI: $10.4000 /$ iss. 422

ISSN: 2306-4161

\section{Publisher}

ICOM - International Council of Museums

\section{Printed version}

Date of publication: 1 December 2015

Number of pages: 101-115

ISSN: 2309-1290

\section{Electronic reference}

Jennifer Harris, «Embodiment in the Museum - What is a Museum? », ICOFOM Study Series [Online],

43b | 2015, Online since 06 February 2018, connection on 19 April 2019. URL : http://

journals.openedition.org/iss/422 ; DOI : 10.4000/iss.422 


\title{
Embodiment in the Museum - What is a Museum?
}

\author{
Jennifer Harris
}

\author{
Curtin University - Australia
}

\begin{abstract}
Examination of the ICOM definition of a museum reveals a conception of the museum institution as an empty container with sharp boundaries between it and its users. None of its meanings seem to be drawn from an interface with people. By contrast, early museums and Renaissance cabinets of curiosities mirrored the power of their wealthy owners and were often installed in their homes, thus signalling strong meaning connections between the owner and the collection - and the owner, the collection and his or her carefully chosen visitors. Being permitted to touch objects was common in this early period, with touch understood to give access to deeper knowledge about artefacts, but the potential damage posed by visitors' bodies was also well known. Classen (2005, p. 276) gives an example of the tension between artefact protection and visitors' expectations: "when the underkeeper of the Ashmolean in 1760 tried to prevent a museum visitor from handling artefacts he was accused of incivility". The tactile rights of visitors were to change radically. From the time of the nineteenth century professionalization of the great national museums, for example, the British Museum and the Louvre, the museum was conceptualized implicitly as a transparent, container-like space in which artefacts and interpretation were displayed as if there were no connection between the exhibits, the exhibition space and visitors, indeed, visitors became an explicit curatorial problem because they could cause damage. The assumed absence of a relationship between artefacts and display space was reinforced by a further crucial assumption, that artefacts could be exhibited in a politically neutral manner as if their meanings emerged only from their physical presence. Institutional self-reflexivity, however, was among the effects of post-colonialism and the New Museology with the result that the political underpinning of the western understanding of museums was exposed and with it the ideological nature of exhibition itself.
\end{abstract}

Adjustments continue to be made to the museum institution as it reconfigures itself in the light of progressive political challenges, but the embodied presence of visitors remains absent in all but management terms - bodies must be kept distant from artefacts, they must be given bathrooms, cafes and public programmes, but the physical and textual realities of bodies in the museum environment is rarely taken into account. It is only in startling museums such as Daniel Libeskind's Jewish Museum Berlin that the reality of the visiting body is regarded as a vital part of the communication process (see Harris, 2012). In most museums, the textual reality of the embodied presence of visitors is ignored. In museum discourse, therefore, artefacts can be seen to have occupied a conceptually higher place than visitors in textual terms because artefacts, at least, have been recognised as existing in the "empty" museum space while visitors have been implicitly conceptualised as a kind of "flotsam and jetsam" that necessarily washes up in the museum space, creating a mess and possibly posing danger - a "category of awkward and 
unwelcome bodies" says Leahy (2012, p. 12) - but almost never contributing fundamentally to the museum text in construction.

Increasing institutional interest in the reading positions of visitors and museums' orientation to their audiences have led to the growth of interactive interpretation strategies. Such strategies, however, often privilege curatorially pre-determined responses and presuppose that visitors are disembodied, that actual bodies moving through exhibition spaces are not the observable reality. Even though control of visitors, and protection of artefacts from them, is a substantial part of any museum management work, interpretation has assumed mostly that the visitor is reduced to a disembodied, surveying eye, a seeing entity whose body is erased in terms of meaning. Visitors, in an odd twist of the indisputable fact of their bodily existence, have had a kind of textual invisibility in the curatorial and managerial imagining of the museum environment. Museums pay ever-increasing attention to visitors via proliferation of visitor studies and exhibitions designed to be engaging but, contradictorily, the reality of the bodily presence of visitors is mostly denied. Leahy's (2012) ground-breaking work on the place of real bodies in museums surveys the history of comportment in European museums. She describes the way in which the polite norms of visiting were formed around managing the bodily presence of visitors. This paper builds on her work to show the implications for the ICOM definition of a museum if visitors' bodies were conceptually reintegrated into museum texts.

This paper argues that by continuing to deny the corporeal, textual presence of visitors, especially of their walking in the exhibition halls, museum professionals are continually misrecognising the museum institution which is conceptualized, in a taken-for-granted mode, as separate from their visitors. Analysis, however, of the walking visitor shows that the museum is not separate from the visitor. Philosophies of walking show that a place comes into being through the human walking presence. This paper begins by considering the nature of space and the conception of vision in a museum before looking at walking philosophies in order to begin to reframe a question which needs to be posed and reposed almost continually: what is a museum?

\section{Space, vision and the ICOM definition of a museum}

The common sense assumption of physical space as an empty container is an everyday norm in the early $21^{\text {st }}$ century. There is a large gap between scholarly investigation of space and the everyday grasp of the concept. Tiwari (2010, p. 14) surveys the major underlying conceptions: space as an empty container in Euclidean and Newtonian philosophy; space as defined by objects and their relationships in the Cartesian conception, and space produced by human practices argued by Foucault (1980) and de Certeau (1984). The latter outline spatial techniques, for example mapping, which "not only represent space but also construct it. There is a relation between knowledge, practice, and the social construction of space" (Tiwari, 2010 , p. 14). She demonstrates how bodies inhabit, construct and represent space through performativity. The highly constrained, implicitly ritualized museum world is an excellent environment from which to look at the relationship between body and space as described by Tiwari. 
Ritual strengthens the relationship between the body and the space, where the body does not view the space from afar, but plays a role in constructing it. Bodily performance becomes an essential part of experience and, in a way, many types of culture performances... become a means to understand life itself. (Tiwari, 2010, p. 31)

The philosophic understanding of the past thirty to forty years has been that space and practice shape each other, but museums, with rare exceptions, appear not to have responded to this paradigmatic shift, they have not perceived the role of the subject in moving through physical space and thereby continually bringing the museum into being. In work reminiscent of Bachelard's (1964) topoanalysis of the intimate spaces inhabited and created by bodies, Tiwari says

It is the body that inscribes its thoughts, emotions, meanings, and memories onto the space, and in the process is transformed. Thus, the notion of body is not as simple as the physical body, but includes ideas of the physical and mental realm, as well as the individual, social and political body associated with it. (Tiwari, 2010, p. 18)

Tiwari differentiates between viewing and inhabiting space.

\begin{abstract}
Space is a palimpsest. Over time, it acquires layers of meaning by the way it is inhabited. These layers of meaning can be uncovered to understand space. What the space denotes is understood by looking at it from a distance with a "viewpoint", but in order to uncover the embedded connotations, it is important to look at it from within by inhabiting it. (Tiwari, 2010, p. 16)
\end{abstract}

The "viewpoint" has been crucial to the operation of museums, setting visitors back from artefacts and reducing them to eyes only. For museum theory, therefore, parallel to the conception of space as an empty container is the concept of ocularcentrism, the idea that vision is our premier mode of knowing the world (Belova, 2012, p. 116). The dominance of vision permeates almost every aspect of contemporary culture. It is central to the operation of contemporary museums and underpins the fundamental "do not touch" prohibition in museums. The curatorial assumption is that looking at artefacts will provide all that visitors require in order to understand exhibitions. Of course, there are noteworthy departures from this assumption so as not to make it an absolute statement, but the rise of, for example, public programmes and affective exhibitions, and both their impact on the body and their textual reliance on the body (Harris, 2012), make only a philosophic dent in what is still an everyday, hegemonic viewing norm. Referencing Bourdieu's (1993) analysis of the aloof, aesthetic gaze, Leahy describes the double decontextualizing movement - that is decontextualizing of both the object from its historic surrounds, and the viewer from her or his body - that resulted in the idealizing of practices of detachment in museums.

Thus the museum produces the artwork as an object of attention and also the corresponding gaze of the disinterested viewer. This idealised gaze is prolonged, focused and also somewhat detached, although... in practice it was (and is) as often transitory and distracted. (Leahy, 2012, p. 5)

The disembodied viewing practice was inculcated as the only correct and acceptable behaviour in museums and disallowed displays of spontaneous emotion or bodily exuberance. Even the famous 
"museum fatigue" (Falk \& Dierking, 2012, p.137), experienced in mind and body, is rarely catered for by museums, with places to rest bodies usually being few, far between, crowded and uncomfortable, suggesting that museums desire visitors to go on walking, although this fundamental ambulatory activity is, ironically, also unacknowledged. Huge visitor tension arises from this irony as management aims to keep visitors walking while their walking presences are assumed to remain outside the museum text. Only outdated, highly conservative conceptions of space and vision could have allowed this tension to be maintained for so long.

Descartes' seventeenth century writing on the importance of detached observation still frames contemporary inquiry methods. The route to knowledge, says Descartes, is by "fixing... eyes on a single point, [to] acquire through practice the ability to make perfect distinctions between things, however minute and delicate" (Descartes, 1637-1701 / 1985, quoted in Belova, 2012, p. 118). He continued by philosophising that the mind then made sense of what the eyes saw: "the objects that I thought I saw with my eyes, I really comprehended only by my mental power of judgement" (Descartes, 1637-1701 / 1954, quoted in Belova, 2012, p. 118). The legacy of Descartes' separation of mind and body is still with us. Belova explains how this separation led also to our conceptual separation from the physical world.

\begin{abstract}
This separation, as well as the idea of sight being an opening of the mind rather than the body, led to establish... observation as an objective, neutral activity, characterised as a detachment rather than engagement with the object of scrutiny. Mind (= sight) was thought to be able to perceive primary measurable qualities of an object... while body (= senses of touch, smell, etc.) could appreciate only its secondary qualities such as odour, texture, and taste. The latter could not be quantified and therefore almost polluted visual perceptions of the primary qualities. (Belova, 2012, p. 118)
\end{abstract}

Evidently, the non-visual senses have had almost no place in the development of the professional, public museum with its links to scientific, detached inquiry. By contrast, the visitor experience in early museums was as much through touch as vision; Classen (2005), noted above in the introduction, describes the importance of tactility in visits to these first museums.

The sense of touch was believed to have access to interior
truths of which sight was unaware. Celia Fiennes noted that
the cane on display in the Ashmolean looked heavy, but
when she picked it up she found that it was light. Touch
functioned to correct the misconceptions of sight... Even in
the eye-minded eighteenth century, when vision was widely
lauded as the basis of cognition, there were still many
considered touch. (Classen, 2005, p. 277)

Ocularcentrism has thus displaced the other senses in understanding. Drawing on the philosophy of Merleau-Ponty (1968), Belova quotes his idea of "flesh" as a counterpoint to ocularcentrism.

"Flesh is not a substance in-between the body and the world but is to be understood 'functionally' as texture, articulation, framework, joints, as an element in which we live and move... An intertwining forms between things, others and myself, a chiasmus or chiasma... [where] [w] hat is one's own and what is not constantly more or less overlap but 
never entirely coincide with each other". Being made of the same stuff, body and the world are part of flesh. (Belova, 2012, p. 121)

Later work on affect by many others (for example, Ahmed, 2004; Deleuze \& Guattari, 1987; Massumi, 2002) has continued to show the interconnectedness of the human body with all facets of existence. The intensity of the experience of living was described in 2002 by Massumi with mind and body richly implicated in the world.

The levels at play could be multiplied to infinity: already mentioned are mind and body, but also volition and cognition, at least two orders of language, expectation and suspense, body depth and epidermis. (Massumi, 2002, p. 33)

In affect analysis, there is no gap between the world and lived human experience, hence no gap between the museum visitor and the exhibition.

Having given the briefest of surveys on space and viewing, I look now at the ICOM definition of a museum in light of the problematization of the human body in the museum space. This revised version of Article Three of the ICOM Statutes was adopted in Vienna in 2007 at the ICOM Triennial.

\footnotetext{
A museum is a non-profit, permanent institution in the service of society and its development, open to the public, which acquires, conserves, researches, communicates and exhibits the tangible and intangible heritage of humanity and its environment for the purposes of education, study and enjoyment.

(International Council of Museum, ICOM Statutes, (2007) Retrieved from http://archives.icom.museum/definition.html/ 2014/04/03)
}

Textually assumed to be disembodied, nevertheless visitors' bodies pervade museums, but where are they in this definition? This definition is focussed on the service elements of a museum, it exists to give to society, but is implicitly independent of it. There is no sense that the museum arises from society or is evidence of that society; the museum, therefore, is itself in a state of detachment. The definition foregrounds the actions of a museum: it "acquires, conserves, researches, communicates and exhibits". All of the actions are initiated by the institution and seem to flow unilaterally outwards to society which, it is implied, is an undifferentiated mass. There is no response, for example, to multicultural elements of evolving societies. The outward flowing of the services of the museum allows for no complex, interconnected communication as has been the assumed norm for reading books and newspapers, and for viewing films and television, for several decades (for example, Fiske, 1982) and is, of course, fundamental to the operation of the internet. The words "communicates and exhibits" imply an outward reach of the museum, but no sense of a reply or of the institution listening and certainly no sense that the visitor is part of the museum text.

\section{Walking}

I now turn to the issue of walking in museums as one aspect of embodiment that can be used to rethink the definition of a museum. The origin of this paper was in 2013 in the royal palace in Petrópolis 
in Brazil, now the Museu Imperial de Petrópolis. This exquisite pink palace in the jungle is very popular with tourists. Beautifully conserved rooms and gardens are enjoyed by thousands, but inside the palace the visitors themselves become a humorous distraction. They are required to slip canvas-based sandals over their existing shoes. The sandals are very large and hamper normal movement. In order to move forward, most visitors adopt what looks like an action akin to cross-country skiing. Some visitors actually swing their arms in order to propel themselves across the highly polished wooden floors. In addition to this most-restricted walking style, museum attendants insist that visitors follow a strict path through the palace. This results in long queues of visitors gliding forward with many swinging their arms incongruously in a regal environment. A strange museum text emerges. The delightful palace rooms remain formal, but are undercut at every turn by hundreds of visitors who are assumed, curatorially, to be invisible. They are anything but invisible, they flood the rooms with their bizarre mobility and become one of the most memorable aspects of a visit to Petrópolis. There are many examples around the world where the restrictions on visitors result in unexpected textual elements that wreak havoc on carefully constructed curatorial texts. The sight of hundreds of pilgrims restrained by police barriers inside the Church of the Holy Sepulchre in Jerusalem, for example, offers a prime example of a clash between the sanctity of the ancient church and the crudity of crowd control thus undermining a prayerful environment. If curators took into account the reality of their embodied visitors in the museum, they might begin to construct texts which incorporated them; their multiple backgrounds and politics would produce dense, rich texts. This paper confines itself to the most fundamental aspect of their reality, walking.

Behind the disembodied eye of the imagined visitor, there is very often a weary body trudging through the halls of a vast institution. Or perhaps one might find the thrilled body of the first-time visitor to a tourist highlight such as the Vatican Museums. Enthused, this body tries to embrace all that the splendid salons have to offer and at some point finds itself in the Sistine Chapel being restrained by attendants from stretching out at length on the floor in order better to view the famous ceiling. Maybe, we should imagine the visitor's body as one of a tired parent carrying an even wearier toddler. All of these bodies are walking in a museum. What does it mean to walk?

Making known scholarly analyses of walking to wider, popular audiences has been bedevilled by walking's taken-for-granted status. This is unfortunate because writing on walking has articulated empowering elements for the ordinary person, making him or her central to textual resistance and generation of narratives. Michel de Certeau's great study of everyday life sets out a triple function of walking by which ordinary people stake a claim to the public world and effectively speak, or enunciate it. He says walking

\footnotetext{
is a process of appropriation of the topographical system on the part of the pedestrian... it is a spatial acting out of the place... and it implies relations among differentiated positions... It thus seems possible to give a preliminary definition of walking as a space of enunciation... Walking affirms, suspects, tries out, transgresses, respects, etc., the trajectories it speaks... (de Certeau, 1984, p. 98)
}

In the many analyses of walking, one finds comparisons of it to speaking, a human trait which is popularly held to share no similarity 
to motion. Lund, however, demonstrates how the landscape is narrated via the walker as a phenomenological aspect of life.

[Walking], consciously or unconsciously [is] an act of exploration because walking is always about heading in a direction; the explorations can be as much directed inwardly, towards the body, as they are directed outwardly, and simultaneously they can be directed both inwardly and outwardly depending on how the body and the landscape enmesh. (Lund, 2012, p. 226)

Lund argues that the world is in formation through acts of walking. Walking does not take place in a pre-formed landscape (Lund, 2012, p. 227). Neither is the self pre-formed, prior to walking.

Traversing the ground is about traversing the self... one is always in a continuous process of becoming... [one] can reveal a sense of belonging in the movement itself that is reflected through the appearance of the landscape... [one] walks through. (Lund, 2012, p. 231)

Landscape and self thus come into being entwined in movement. Psychogeography offers many examples of making the self and landscape through walking. Smith (2010, p. 120), for example, revisits the Situationists' dérive and arrives at mythogeography. Algorhythmic walking in Venice offers another example: always taking the first turn to the left and then the second to the right demonstrates lived experience as mapping (Whybrow, 2011, p. 282) and paves the way for "mappings to take the form of embodied responses to the city" ( $p$. 288). Specific psychogeographic political intentions include walking as a subversive act which insists on seeing the city as mysterious and walking to overcome its banal characteristics (Coverley, 2006, p. 14). The great value of the work of Lund, which includes an analysis of such everyday activities as managing heavy shopping bags while negotiating sharp winds and slippery surfaces outside a supermarket in Iceland, is that it shows that one need only to be mindful in order to understand oneself as coming into being through acts of walking, that awareness of the power of walking requires only an act of reflection. Recalling the recent tussle with wind and ice in Reykavik, she says,

\begin{abstract}
I tried to organise this short trip to the shop in my head as I jotted down a few notes. In contrast to the surroundings of my living room it felt somehow disorderly, obscure and difficult to put the notes together into a linear sequence. There were initially no forms in which I could express my experience, only entangled but muddled feelings of discomfort. It was only with effort that I could put the experience into a coherent narrative. (Lund, 2012, p. 277)
\end{abstract}

Several writers have developed the enunciative function of walking as narrating the landscape and bringing coherence to it. Forgione's discussion of the concepts of walking in nineteenth century Paris focuses on many of the iconic Impressionist paintings of the everyday as expressions of combined seeing and walking.

My account, then, proposes to complicate or revise our traditional sense of the Impressionists as forging an "optical" practice. What emerges in these pictures is a sophisticated alertness to precisely the coherent intertwining of body, mind, and vision insisted on in the history of writing about walking. (Forgione, 2005, p. 664) 
The linking of body, mind and vision is crucial for museum analysis, which has proceeded usually with an assumption of the disembodied eye carrying the "gaze of the disinterested viewer" (Leahy, 2012, p. 4). If we re-conceptualise the visitor as a full corporeal creature, in which mind, body and vision work together, then, to date, almost all assumptions about visitors in exhibition spaces appear far from reality and suggest the misrecognition of the identities of both visitors and institutions. Merleau-Ponty (1968) and later writers on affect have philosophized an unshakeable connection between bodies and the world, in fact interconnectedness. The inner world of the visitor can be seen to merge with the outer world, the energising quality of walking giving rise to what Leahy $(2012, p .79)$ describes as an "intense feeling of self-presence". Forgione alerts us to the long history of thinking about walking's ability to produce us as beings integrated with, rather than separate from, our environment.

\begin{abstract}
Walking's ability to integrate inner and outer worlds is a consistent theme in the literature on the subject, which holds the process to operate in this way: the physical motions of ambulation activate the walker's inner, thinking self and thereby bring that self into contact with the external world, an encounter that gives rise to a reciprocal exchange or oscillating flow between inward and outward attention. That account of how walking actually works in experience emerged with increasing clarity during the nineteenth century. (Forgione, 2005, p. 669)
\end{abstract}

The inner and outer link afforded by walking is not acknowledged by museums, even when they propose walks to the visitor. Attempts by museums all over the world to restrict walking to specified trails developed ostensibly for efficiency or linear flow of objects - cannot encapsulate the embodied meaning experiences of visitors. The Vatican Museums' famous trails, which were set out to assist visitors in reaching their key points of interests in the most efficient manner, are constantly resisted. Visitors double back, move across monumental stairways to join other trails and call out to others on different trails. Walking blurs objects, negates curatorial comment and invents pathways unknown to the museum. Writing of the endless variety in walking, even over the same terrain, for example of an apparently static museum space, de Certeau observes:

\begin{abstract}
all the modalities sing a part in this chorus, changing from step to step, stepping in through proportions, sequences, and intensities which vary according to the time the path taken and the walker. These enunciatory operations are of an unlimited diversity. They therefore cannot be reduced to the graphic trail. (de Certeau, 1984, p. 99)
\end{abstract}

There are signs that, even in the context of opening up to visitors, the most progressive of curators still move to restrict or incorporate the reality of visitors' bodies in exhibition halls. Falk and Dierking take it as a standard fact that there is high predictability in museum behaviour because they are

\footnotetext{
"behavior settings" which elicit common suites of behaviors. Many of the people entering the museum have learned what to expect and how they and others should behave to insure that "correct" and "appropriate" behaviors for a place such as this are followed. (Falk \& Dierking, 2012, p. 144)
}

The restrictions are not so much corporeal as they were, say, thirty years ago; today the restriction is often more fundamental, denying 
visitors a role in generating meaning by the incorporation of "aberrant" meanings. Leahy (2012) describes the colonisation of the vast Turbine Hall by visitors at Tate Modern in London as being so intense that it can undermine the works on display. She refers to the experiences of the exhibition of Shibboleth by Doris Salcedo, a giant crack in the floor over which visitors could wander, leap or even insert their arms and hands. She notes that visitors have become "performatively attuned" (Leahy, 2012, p. 111) to the extreme point of resisting exhibitions. The visitors' atmosphere at Tate Modern worked against the expected dark mood of Shibboleth.

\begin{abstract}
the audience at Tate Modern had become used to consuming the Turbine Hall as playground and photo opportunity: it was impossible for Shibboleth to project its more sombre message onto the flow of pleasured, entertainment-seeking and self-conscious bodies. The issue was not so much whether certain corporeal responses were more or less appropriate to the work, but rather the recognition that the bodies of visitors were interpretative agents that were generating new meanings of Shibboleth through their actions and reactions. These were improvisational bodies acting against the institutional and artistic intention by encountering the world on their own terms. (Leahy, 2012, p. 111)
\end{abstract}

Given the extensive writing on empowerment of museum visitors and the ideals of incorporating them into exhibition texts, one might have expected that Tate Modern would perhaps record the meanings made by visitors as a way of adding to the possible meanings of the work. The opposite, of course, was the reality; the institution preferred to maintain control of meaning as much as possible, despite its current vision statement about its open relationship to its audiences.

Tate's 2015 vision is to be more

Open by being receptive to new ideas, encouraging debate, exchange and collaboration within and beyond Tate, and by being more inviting to more people ("Tate Modern, Mission 2015", 2014).

A positive attitude to the power of visitors is evident in the vision statement, but it appears to have been at odds with the museum's reaction to the unexpected and unwelcome behaviour of visitors during the exhibition of Shibboleth. Leahy describes the multitude of visitor responses, including falling into the crack, as running counter to museum authority.

\footnotetext{
The moment of dissent was, however, fleeting as the museum swiftly reincorporated these "transgressive" bodies into a strategy of audience development that embraced both the contrasting corporeal regimes of the modernist white cube gallery and the permissive "street" of the Turbine Hall. (Leahy, 2012, p. 112)
}

The experience at Tate Modern highlights the intriguing museological moment in which we now find ourselves. On one hand, museums are full of rhetoric about the activities of visitors and, on the other, are certainly not yet ready to relinquish their authority by recognising the corporeal presence of their visitors.

Ironically, despite seeming to insist on old authority modes, museums are opening up to art installations which explore the body in the museum. There are several examples of such artworks. Tino Sehgal's 
"constructed situations" ("Tino Sehgal", n.d.) bring about live encounters between people in museums; this is sometimes very uncomfortable for visitors, making them aware of their bodies in the museum space and new and possibly unwanted ways of making meaning. His work is not documented officially and exists only in the memory of those who experienced it. Marina Abramović Presents (Leahy, 2012, p. 86) explored museum walking in Whitworth Art Gallery in Manchester in 2009. Abramović's performance art, "The Public Drill", curated visitors' bodies by drilling them in new walking and looking methods. After an hour of preparatory drilling, visitors were free to wander in the museum, the expectation being that the drill would have set up an interrogation of any previous museum visiting habits. Noteworthy also is Martin Creed's running exhibition Work No. 850 (Leahy, 2012, p. 87), in which a series of people ran through Tate Britain overturning all firmly held decorum and thus bringing it into question. If museums are prepared to host exhibitions that query the visiting habits of visitors, especially of their walking, it must surely be time for museums to include reflection on corporeality in the museum definition.

\section{A new definition of a museum?}

This paper will not attempt to redefine a museum, but will gesture towards issues that will need to be taken into account when doing so in the light of potential and urgent recognition of embodied visitors. It is evident that, although I note these issues in relation to visitor embodiment, they have already been highlighted in critical responses over the past twenty years to the many challenges of postmodernity and post-colonialism.

First, rather than being preliminary producers of narratives, museums would become understood as spaces of multiple narratives brought into being via visitors' walking. The first implication of this would be that rather than seeking to control meaning, as was possibly the case at Tate Modern noted above, the museum would be a space in which conflicting narratives could co-exist as an habitual, institutional enablement. The museum itself would thus be in a state of becoming, an open-ended institution.

Secondly, the critical textual move away from an emphasis on the producer (curator and museum as an authoring institution) and the product (exhibition) as the key components of museum meaning would seem completed by the acknowledgment of embodiment. There has been a gradual acceptance of the visitor via exhibitions which promote dialogue, but an embodied presence, rather than a restricted mental presence, would go further. As noted earlier in this paper, the acceptance of an embodied presence is rare, with exceptions proving the rule of assumed disembodiment. Hence, Daniel Libeskind's Jewish Museum Berlin and Te Papa in New Zealand, which rely on the visitor's emotional and bodily responses, remain among only a handful of institutions to do so.

Embodiment would be likely to give rise to certain responses that have not been permissible for a long time. Highly emotional engagement, for example, could be expected. Currently, the only expectation of emotionality by museums has been in relation to Stendhal's Syndrome, the experience of which leaves the visitor overwhelmed by the coincidence of great art, history and often 
religion to the point of psychiatric collapse. Stendhal's Syndrome, in the current museum climate, is regarded as an exception.

If embodiment were anticipated, then intense emotionality might be expected and worked into exhibitions. After many decades of the hegemony of viewing detachment, the idea of emotionality has often seemed completely out of place in the museum, even laughable to some because displays of emotion are often understood in the western world to be signs of loss of control and even irrationality. There are, however, many examples where detachment has broken down or abandonment of it urged. The Ave Maria Purissima exhibition in Cebu in the Philippines allowed the viewing of 27 famous images of the Virgin Mary. The exhibition curator urged visitors to the exhibition in Cebu Cathedral Museum to pray ("Ave Maria Purissima", 2013). Although the religious environment of the exhibition might suggest that an emotional religious response was not out of the ordinary, it is important to note that the exhibition took place in the museum, not in the Cathedral itself. The broader museum environment is not associated today with emotional expression, for example the Vatican Museums are not particularly sacred until one reaches the Sistine Chapel where attendants have the difficult task of imposing a solemn environment on rowdy visitors. Likewise, the Louvre has hundreds of masterpieces which were designed for display in churches, but which have found their way to the dispassionate viewing environment of the Louvre. In this wider context, the call to prayer in front of images is indeed highly unusual. Strong emotionality and even transcendence, however, are far from unusual in the museum environment. Soren (2009) and Latham (2012) describe experiences in which visitors have felt outside themselves transported and in mystical connection with the universe. Of particular interest for this paper is Latham's description of people experiencing unsettling and profoundly moving museum moments through their bodies.

\begin{abstract}
A numinous event is characterised by several physically, visually, and spatially perceived elements. Participants actually felt time and space alter and physically reacted to the encounter through their body. (Latham, 2012, p. 10)
\end{abstract}

If the most intense of encounters are to be experienced via the body, then it is a duty of museums to embrace it in exhibition.

Thirdly, we would need to live with the idea of incompletion. Such disquiet, of course, has been part of postmodernity for at least thirty years, but there has been a nostalgic longing for this not to be the case in museums, expressed in a myriad of ways related to lingering museum authority. Carr speaks of this disquiet in positive terms.

The purpose of the museum at its best is, like the purpose of a great educator, to cause some kind of troubling incompleteness for the user, and so to inspire human change. (Carr, 2001, p. 176)

Museum exhibitions that aim to provoke visitors to question, comment and learn more have been a museological ideal for some long time. Carr's description of a positive "incompleteness" at the heart of the museum experience emerges from the idea of performativity - that visitors are in a performing environment which necessarily leads to open-ended experiences. 
world... every museum user needs the opportunity to move, mind and body, into the narrative until it merges with the user's own. (Carr, 2001, p. 182)

Rather than working with the visitor's narrative, it might be more accurate to speak of a new narrative emerging through each visitor. Lund reminds us that

\begin{abstract}
paths and routes that the wandering feet follow shape stories as they direct the walks, and are simultaneously shaped during the course of the walk. Different narratives provide a different ambience and each has its own character. Sometimes they flow smoothly but sometimes the tone can be disorderly and even troublesome depending on how the landscape lends itself to the walking body and how the walker lends him / herself to the landscape. (Lund, 2012, p. 226)
\end{abstract}

Arnold's (2012, p. 29) thoughts on a new kind of "aesthetic of labyrinthine open-endedness, of permanent incompletion and perpetual (self) questioning by testing the limits" are useful. Such open-endedness could lead to great dynamism of meaning.

Fourthly, performativity would be recognised in a new museum definition. The idea of a separate space for the museum, utterly disconnected from the disembodied visitor who is reduced to an eye, would seem textually impossible. The performative qualities of the visitor would be valued side-by-side with the value of artefacts. The concept of visitor interaction with artefacts, as opposed to the simple viewing of them, would become a reality of museum experiences. This is not to suggest that artefacts ought to be placed in danger, nor that routine touching, common in previous centuries, ought to be reinstated. Obviously, artefacts precious to the whole community would need to be protected from physical damage. Copies, however, already made for sight-impaired visitors, and in other centuries for art students and museums without original objects, might well become a new norm in museums as the central importance of visitor performativity transcends artefact auraticism.

\title{
Conclusion
}

In recognising the embodied presence of visitors in museum spaces, we are left with questions, but very few answers. This paper has argued that the ICOM definition of a museum is now outmoded because it does not incorporate an understanding of the textually embodied presence of visitors. This paper has also suggested that even the most progressive of museums, such as Tate Modern, are likely to have difficulties in managing or responding to chaotic generations of meaning.

Should museums attempt routinely to capture the plethora of meanings that become available via visitors? This is a difficult question to answer and has been floating around ever since commentators in the field began to realise that the producer (or artist or curator) and the product (or exhibition or art work) were only two parts of a triangle of meaning. Would we all be interested in hearing about the meanings of others? Do we prefer to encounter the product or artwork in solitude? Various critics have collected multiple meanings, very often in order to mount arguments concerning widespread resistance to control of meaning. The meanings that were 
collected were usually those that were able to be explained very clearly by highly articulate visitors, often in response to carefully framed questions by the investigator. If we are now to move beyond cerebral meanings to addressing issues of the corporeal entwined with the cerebral, we face new challenges of accessing meaning. Do we wish to push visitors to explain meanings that they experienced so strongly via the body that they were difficult to articulate, for example those that were experienced by Lund (2012) on her icy return from the supermarket? What would it mean for museums to flood us with intense meanings including the dispassionate, detached experiences of others?

Another area of questioning concerns empowering embodied visitors. Is there a way that we can give more to visitors in recognising their embodied presence? At this time in museological history, the most useful thing we can do is be alive to the pending revelation of new museum realities. We should start by addressing the issue of redefining a museum.

\section{References}

Ahmed, S. (2004). The Cultural Politics of Emotion. New York: Routledge.

Arnold-de Simine, S. (2012). Memory museum and museum text: Intermediality in Daniel Libeskind's Jewish Museum and W.G.Sebald's Austerlitz. Theory Culture and Society, 29(14), 14-35.

Ave Maria Purissima. (2013, December 4) Retrieved from http://www.sunstar.com.ph /cebu/local-news/2013/09/07/visitors-toldpray-while-looking-marian-images-302079/ 2013/12/04.

Bachelard, G. (1964). The Poetics of Space. Boston: Beacon Press.

Belova, O. (2012). The event of seeing: A phenomenological perspective on visual sense-making. In Dudley, S. (Ed.). Museum Objects: Experiencing the properties of things (pp.) Hoboken, Taylor and Francis, 117-133.

Bourdieu, P., \& Johnson, R. (Ed.). (1993). The Field of Cultural Production., Cambridge: Polity Press.

Carr, D. (2001). A museum is an open work. International Journal of Heritage Studies, 7(2) 173-183.

de Certeau, M. (1984). The Practice of Everyday Life. Berkeley, Los Angeles, London: University of California Press.

Classen, C. (2005). Touch in the museum. In Classen, C. (Ed.). The Book of Touch. Oxford and New York: Berg.

Coverley, M. (2006). Psychogeography. Happendale, Herts: Pocket Essentials.

Deleuze, G., \& Guattari, F. (1987). A Thousand Plateaus: Capitalism and schizophrenia, Minneapolis: University of Minnesota Press.

Descartes, R. trans. Anscombe, E. and Geach, P.T. (1637-1701 / 1954). Philosophical Writings. Edinburgh: Nelson.

Descartes, R. trans. Cottingham, J., Stoothoff, R. and Murdoch D. (16371701 / 1985), Philosophical Writings. Cambridge: Cambridge University Press.

Falk, J., \& Dierking, L. (2012). Museum Experience Revisited. Walnut Creek: Left Coast Press.

Fiske, J. (1982). Introduction to Communication Studies. London and New York: Methuen.

Forgione, N. (2005). Everyday life in motion: The art of walking in latenineteenth-century Paris. The Art Bulletin, 87(4), 664-687.

Foucault, M. (1980). Language, Counter-Memory Practice, Ithaca, NY: Cornell University Press.

Harris, J. (2012). Turning to the visitor's body: Affective exhibition and the limits of representation. ICOFOM Study Series, 41, 121-133.

International Council of Museums, ICOM Statutes. (2013, December 4) Available from http://icom.museum/the-organisation/icom-statutes/ 
Latham, K. (2012). Numinous experiences with museum objects. Visitor Studies, 16(1), 3-20.

Leahy, H. (2012). Museum Bodies: The Politics and Practices of Visiting and Viewing. Farnham: Ashgate Publishing Ltd.

Lund, K. (2012). Landscapes and narratives: Compositions and the walking body. Landscape Research, 37(2), 225-237.

Massumi, B. (2002). Parables for the Virtual: Movement, Affect, Sensation. Durham and London: Duke University Press.

Merleau-Ponty, M. (1968). The Visible and the Invisible. Evanston: Northwestern University Press, 1968.

Smith, P. (2010). The contemporary dérive: A partial review of issues concerning the contemporary practice of psychogeography. Cultural Geographies, 17, 103-122.

Soren, B. (2009). Museum experiences that change visitors. Museum Management and Curatorship. 24(3), 233-251.

Tino Sehgal. (n.d.). in Wikipedia. Retrieved April 20, 2015, from http://en.wikipedia.org /wiki/Tino_Sehgal

Tate Modern Vision 2015. Retrieved from http://www.tate.org.uk/about/ourwork/our-priorities/2014/04/04

Tiwari, R. (2010). Space-Body-Ritual: Performativity in the City. Lanham, Maryland: Lexington Books.

Whybrow, N. (2011). Situation Venice: Towards a performative 'ex-planation' of the city. Research in Drama Education: The Journal of Applied Theatre and Performance, 16(20), 279-298.

\section{Abstract}

Challenges to museum curatorial control of meaning, combined with interest in the reading positions of visitors, have led to the growth of interactive interpretation strategies. Such strategies, however, often privilege curatorial pre-determined responses and presuppose that visitors are disembodied, that actual bodies moving through exhibition spaces are not, in fact, the palpable reality of a museum experience. Visitors have a kind of textual invisibility. Consideration of visitor performativity and embodiment in museums poses an exhilarating museological challenge. Museums need to come to terms with the bodily aspects of a museum visit, understanding that visitors enact their narrations of the museum as they walk through it. This paper argues that, by textually denying the corporeal presence of visitors, museums continually misrecognise their own institutional identity as they theorize themselves as separate from the visitor. Examination of the walking visitor shows that a museum is not separate from the visitor, but comes into being through her or his walking presence. What impact does this have on the definition of a museum?

\section{Résumé}

Incarnation des visiteurs au musée. Qu'est-ce qu'un musée ?

Les défis au contrôle du sens par le conservateur, combinés avec l'intérêt porté aux positions de lecture des visiteurs ont conduit au développement de stratégies d'interprétation interactives. Néanmoins, de telles stratégies privilégient souvent des réponses prédéterminées par le conservateur et présupposent que les visiteurs sont désincarnés, que les corps qui se déplacent dans l'espace de l'exposition ne constituent pas en fait la réalité de l'expérience du musée. Les visiteurs ont de fait une invisibilité textuelle. La prise en considération de la performativité et de l'incarnation du visiteur dans un musée représente un défi pour la muséologie. Les musées doivent admettre la physicalité d'une visite au musée, acceptant le fait que les visiteurs mettent en scène leurs récits alors qu'ils se déplacent. Cet article soutient qu'en niant la présence corporelle des visiteurs, les musées s'illusionnent continuellement sur leur propre identité, se percevant comme une 
entité séparée. L'examen du visiteur incarné montre que c'est par le fait même de sa présence en mouvement qu'un musée se met à exister. Quel va en être l'impact sur la définition d'un musée ? 